Postscript. Since writing the above paper, Mr. A. P. Morse has called my attention to an article in the American Museum Journal of February, 1918, p. 145, by Mr. W. L. McAtee who quotes Mr. E. A. Goldman of the U. S. Biological Survey mentioning a curious instance of synchronal insect movements: "When looking among the tree tops for birds, he has been taken unawares by an army of these (driver) ants. The soldiers of the driver ants have tremendously developed heads and jaws; their bite brings blood and they hang on till the heads are pulled off. The most interesting feature of their attack is the remarkable unanimity with which they set their teeth (?) into the skin. Whether they accomplish this by mental telepathy or otherwise, the fact remains that several ants scattered here and there over one's anatomy all decide to bite at one particular moment."

It may be that the action of the pulse was the stimulating influence that caused the ants to bite Mr. McAtee all at the same moment. Prof. W. M. Wheeler writes me: "There is doubt in my mind about McAtee's interpretation of the simultaneous biting of the soldiers of the driver ants. It may be merely a simultaneous response to the movement of the body of the person covered with ants. Such a movement of the skin would act as a stimulus and cause all the irritated ants to use their mandibles at the same moment. I have a feeling that I have noticed something of the kind in the tropics in other ants."

\title{
NEW RECORDS OF ORTHOPTERA IN NEW ENGLAND.
}

\author{
By Albert P. Morse. \\ Wellesley College, Wellesley, Mass.
}

Parcoblatta lata Brunner. This common native wood-roach of more southern range (formerly placed in genus Ischnoptera) has been taken in New England in a single instance. It was captured by me on July 13 on the ground floor of a dwelling-house at Wellesley, Mass., and identified and recorded by Hebard, who regards it as adventive in New England.

Manomera blatchleyi Caudell. An adult female of this walkingstick was taken by me at Greenwich, Conn., August 25, 1892, and 
laid eggs after capture. An immature female was taken at the same place and time.

Amblycorypha floridana carinata Rehn and Hebard. Half a dozen examples of this northern race of a southern katydid are recorded by Rehn and Hebard from Nantucket and Woods Hole, Mass.

Scudderia curvicauda borealis Rehn and Hebard. This is a diminutive boreal race of our common Curve-tailed Bush-Katydid. I took a very few examples at Orono in central, and Cherryfield and Whitneyville in eastern Maine, August 5 to 30, 1913. These were found among shrubbery on cold, heath-grown bogs.

Conocephalus spartince Fox. This brightly-colored little longhorned grasshopper is locally abundant on saltmarshes along the New England coast. Fox described it from Woods Hole, Mass. I took it years ago at Stamford and Niantic, Conn.; at Faneuil Station, Mass., before the construction of the Charles River Basin and the freshening of the marsh at that point; and more recently. at Rowley, Mass., and York Beach and Pine Point near Old Orchard, Me. It is in the Scudder collection from Cape Cod. It thus agrees closely in extent of distribution in New England with the Seaside Locust, Trimerotropis maritima.

Conocephalus saltans Scudder. Locally common on the sandy moors of Nantucket, Mass., among bunchgrass (Andropogon scoparius), wild indigo (Baptisia tinctoria), and huckleberry bushes. The presence of this flightless grasshopper on Nantucket is of especial significance in its bearing on the geological conditions which resulted in the dispersal and present distribution of the characteristic plants and animals of the sandy coast-plain of New Jersey northeastward.

Diestrammena marmorata DeHaan. This Asiatic cave- or camelcricket has established itself from time to time in greenhouses and cellars nearly all over the world. It has been sent me from Kennebunk, Me., and Springfield, Mass., and I have taken it in numbers at Danvers, Mass., a locality first called to my attention by the late Rev. H. W. Winkley.

Ceuthophilus gracilipes var. stygius Scudder. A male, taken at Beverly, Mass., is in the collection of the Boston Society of Natural History. 
Ceuthophilus neglectus Scudder. (Diagnostic note.) This species differs from all our other New England species in the structure of the abdomen of the male and can usually be recognized at once by the yellowish color of the underparts, and the following points: the ninth tergum is usually completely hidden by the crescentically thickened parabolic hind margin of the eighth tergum; the subgenital plate is also distinctive,-short, scoop-shaped, with thickened, semicircular, nearly horizontal margin.

Nemobius griseus E. M. Walker. I have taken this cricket sparingly on sandy tracts at Brunswick, Me., Provincetown, and South Sudbury, Mass., in September.

Nemobius maculatus Blatchley. Mr. B. H. Walden has sent me this species from New Canaan, Conn., taken in September.

Gryllotalpa vulgaris Latreille. I found three examples of this, the common European mole-cricket, in the collection of local insects of the Maria Mitchell Scientific Association at Nantucket. They were without data but believed to have been taken on the island. This is highly probable, since another European orthopteron, a flightless bush-katydid, Leptophyes punctatissima, has been captured there by Prof. H. T. Fernald. Both species were doubtless introduced in commercial importations of plant material from Europe, such as Scotch broom, pines, and heather.

Acrydium granulatum incurvatum Hancock. This is the western broad-shouldered form of our common Angulate Pygmy or Grouse Locust. Mr. C. W. Johnson has taken examples at Capens and Sugar Island, Moosehead Lake, Me., in July.

Acrydium hancocki Morse. This robust ally of our common Ornate Pygmy Locust, described from and common in Iowa, I took at Randolph, N. H., in July, 1898, and in the summer of 1913 found it at Fort Kent, Fort Fairfield, and Houlton, Me., August 24 to 28.

Acrydium arenosum angustum Hancock. This Pygmy Locust is well-distributed in New England. I have taken it at various points from Cherryfield in eastern Maine, and Newport in northern Vermont, to Nantucket, Mass., and New Haven, Conn. 

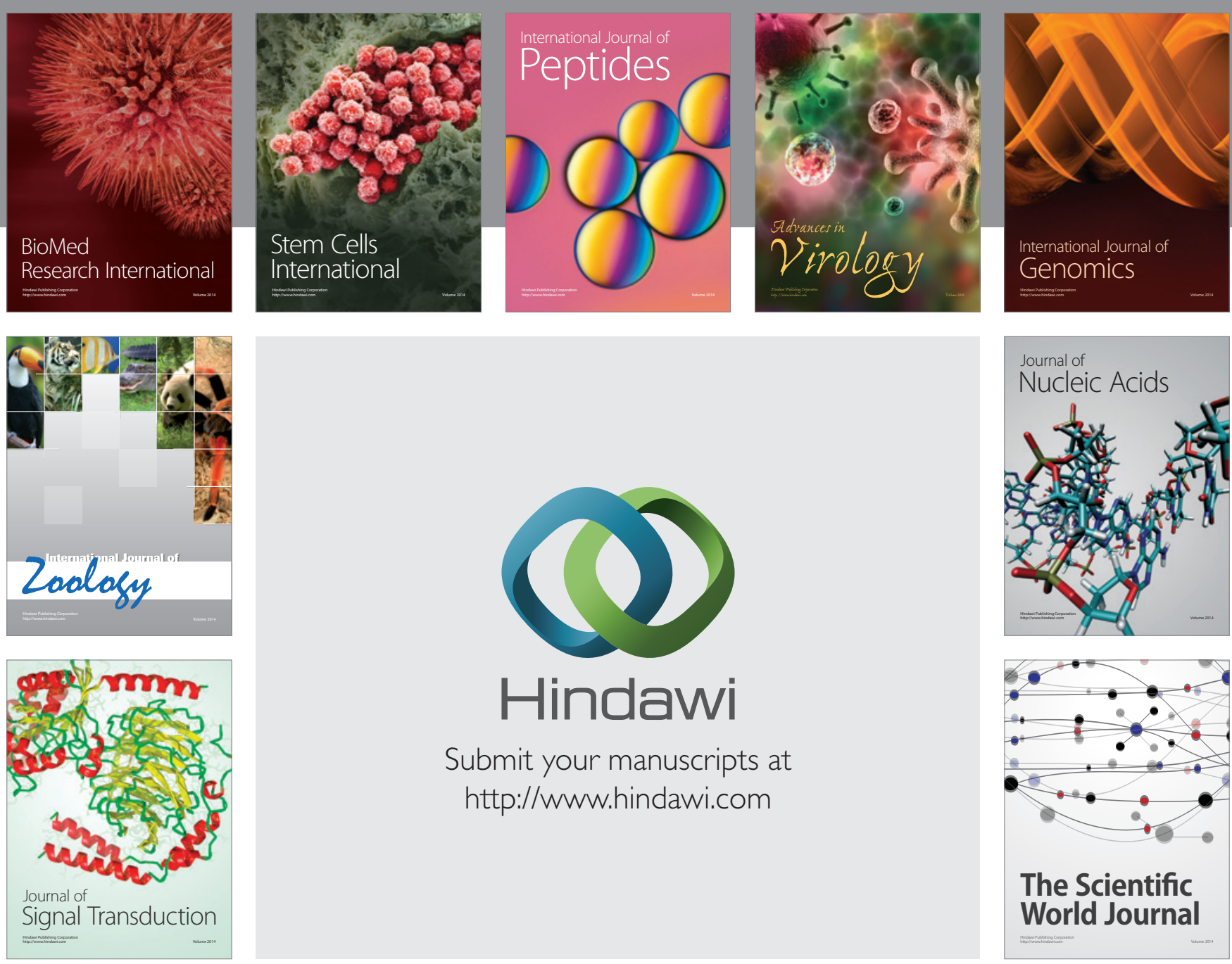

Submit your manuscripts at

http://www.hindawi.com
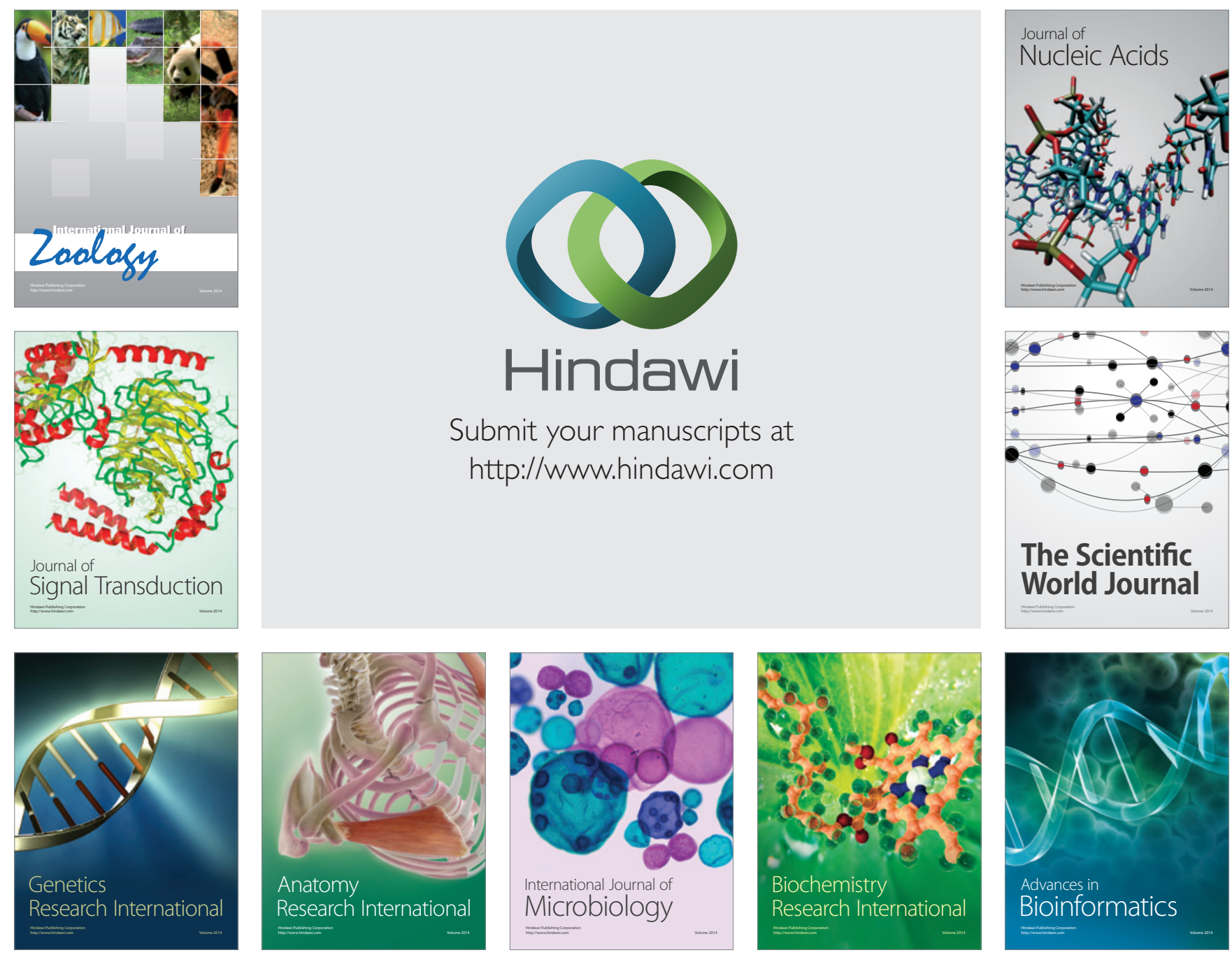

The Scientific World Journal
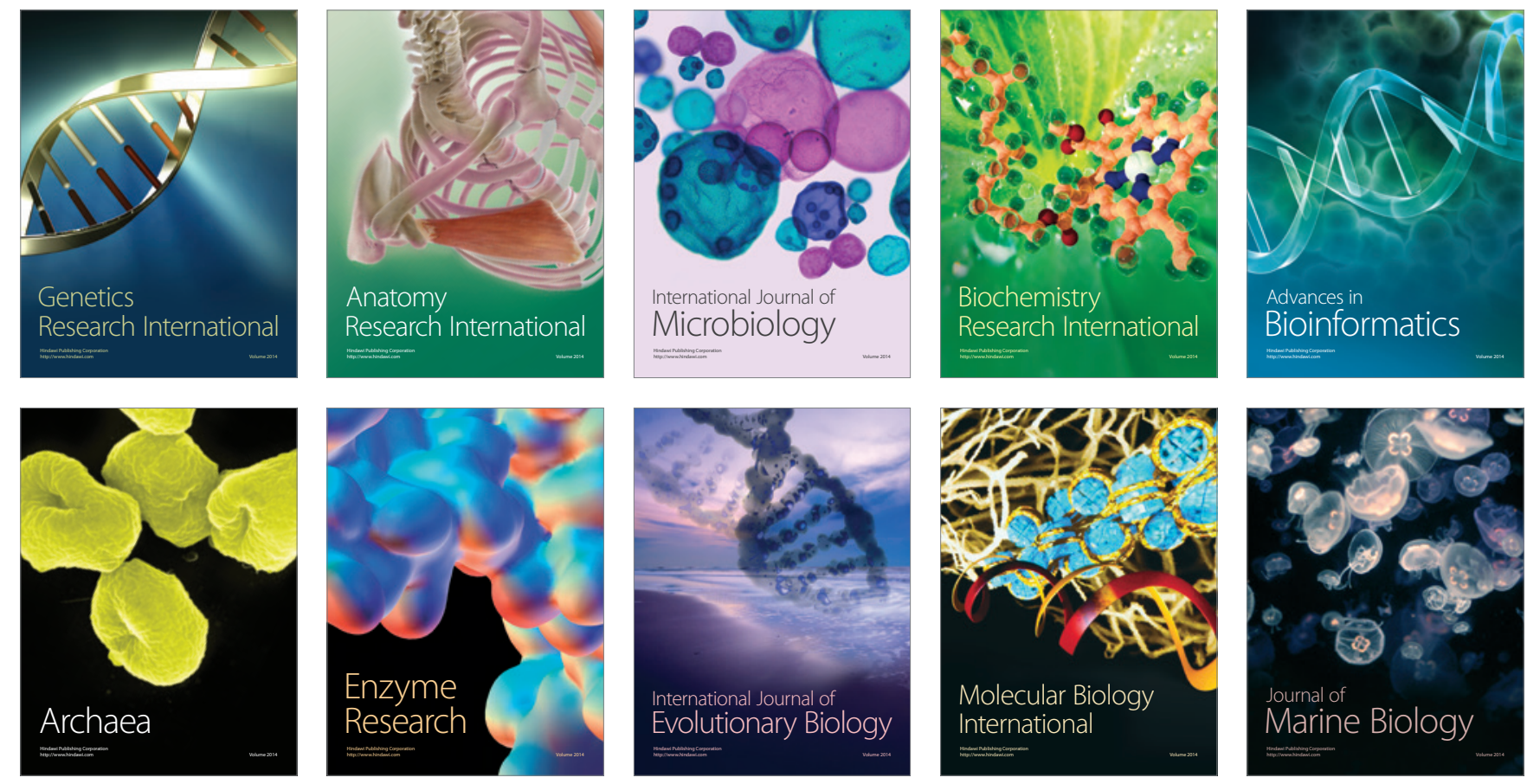